\title{
Sulfur isotope fractionation and sequential extraction to assess metal contamination on lake and river sediments
}

\author{
Lívia Ribeiro de Souza $^{1}$ - Kay Knöller ${ }^{2}$ Ana Cláudia Queiroz Ladeira ${ }^{1}$
}

Received: 29 May 2015 / Accepted: 17 March 2016/Published online: 2 April 2016

(C) The Author(s) 2016. This article is published with open access at Springerlink.com

\begin{abstract}
Purpose The present study investigated lake and river sediments affected by metals from an acid mine drainage (AMD) from a former uranium mine. The role of bacterial sulfate reduction in the immobilization of contaminants was evaluated, and the analyses of acid volatile sulfide (AVS) and sequential extraction were performed. Consequently, the potential mobility and bioavailability of contaminants were established. Materials and methods Sulfur isotopic fractionation $\left(\delta^{34} \mathrm{~S}\right)$, AVS, and sequential extraction procedure were used to assess the sulfate bacterial reduction and the availability of contaminants in the environment at six sampling stations.

Results and discussion The $\delta^{34} \mathrm{~S}$ indicated that bacterial reduction is a key process in the natural attenuation of contamination in the Águas Claras reservoir, precipitating metal sulfides. According to the USEPA criteria, adverse biological effects are expected for sample S1 (inside the reservoir) which is likely to be toxic, while for sediment S4 (in the river), the toxicity is uncertain. The other samples were classified as nontoxic, likely because of the decreased solubility of zinc sulfide. A decrease in the concentration of the contaminants downstream of the reservoir was observed. The predominance of $\mathrm{U}(0.4 \%)$ in the labile fraction and the elevated concentrations of $\mathrm{Zn}(0.5 \%)$ and $\mathrm{Mn}(0.7 \%)$ in the sediments inside the
\end{abstract}

Responsible editor: Marcel van der Perk

Lívia Ribeiro de Souza

lrds2@cam.ac.uk

1 Department of Mineral Processing, Center for the Development of Nuclear Technology, CDTN, Belo Horizonte, Brazil

2 Department of Catchment Hydrology, UFZ Helmholtz Centre for Environmental Research, 06120 Halle, Germany reservoir raises concerns regarding the availability of these contaminants in the environment.

Conclusions The main environmental impact appears to be concentrated in the Águas Claras reservoir, whereas the Antas creek does not seem to be affected by the AMD process. Although the bacterial sulfate reduction is effective in its production of sulfides capable of immobilizing the contaminants, the presence of $\mathrm{Zn}$ and $\mathrm{U}$ in the labile and reducible fraction is a matter of concern due to its long-term bioavailability. Thus, continuous monitoring of the redox potential of the waters and sediments, mainly in the reservoir, is recommended in order to assess and possibly prevent later dissolution of sequestered contaminants.

Keywords Acid volatilesulfides - Bacterial sulfate reduction · Metals $\cdot$ Sediments $\cdot$ Sulfur isotopes

\section{Introduction}

Acid mine drainage (AMD) is a critical environmental issue caused by chemical and bacterial oxidation of pyrite $\left(\mathrm{FeS}_{2}\right)$ and other sulfide bearing minerals exposed to atmospheric conditions during the mining of metal ores and coal (Taylor et al. 1984; Balci et al. 2007). As a result, the generation of acidic waters containing a wide array of toxic metals and sulfur species, mainly sulfate, eventually reaches rivers, groundwaters, and lakes and has adverse effects to both flora and fauna. In particular, dissolved and sedimentary sulfur species and their transformations play an essential role in the hydrochemistry of the waters, since the content of dissolved metals can increase or decrease through interaction with them (Knöller et al. 2004; Sarmiento et al. 2009). Sulfate from the AMD can be reduced to sulfide due to bacterial action and can be assessed trough isotopic analyses. In general, the sulfates 
with lighter sulfur isotopes are more readily metabolized because their bonds are weaker (Seal 2003). As a consequence, a distinct sulfur isotopic signature in sulfide is produced by a depletion in ${ }^{34} \mathrm{~S}$ with values as high as $46 \%$ (Rees 1973; Habicht and Canfield 1997) or even depletion up to $75 \%$ as reported by Brunner (2005). Once formed, the sulfide can react with divalent metals to form insoluble sulfides, such as $\mathrm{FeS}, \mathrm{ZnS}$, and $\mathrm{CuS}$, decreasing the chemical activity and thus the bioavailability of these contaminants (USEPA 2005). In addition, the metastable iron monosulfides (FeS) can be a precursor of pyrite $\left(\mathrm{FeS}_{2}\right)$ that is a fairly stable sulfide which is capable of adsorbing contaminants. Therefore, the assessment of sulfur isotopic fractionation, the quantification of the sulfides, and the determination of the solid phases along with their association with the contaminants are essential for the following reasons: firstly they provide information about distribution, mobility, and bioavailability of the contaminants, and secondly, they indicate the occurrence of natural attenuation processes (Morillo et al. 2008; Sarmiento et al. 2009; Byrne et al. 2010; Charriau et al. 2011).

In Brazil, AMD occurs in a former uranium (U) mine and contains radionuclides and other elements, which are precipitated from the acid water by liming. Due to the inefficiency of the acid water treatment, contaminants overflow from the settling ponds and end up at the Águas Claras reservoir, leading to a concern about their migration to the environment, mainly to the Antas creek (Rodgher et al. 2013). The multiplicity of interactions between the contaminants and the sediments requires a broader approach in order to understand the fixation and/or transport of a wide range of elements, including $\mathrm{U}$. Within this framework, a combination of different techniques was used to elucidate the bio-availability of the most hazardous contaminants present in surficial sediments from the Águas Claras reservoir and Antas creek. Sulfur isotopic fractionation was used to assess the occurrence of the bacterial reduction process. Additionally, the sediment's toxicity was predicted based upon the interactions of toxic metals with the sulfide and organic matter. Finally, the availability of contaminants was assessed by a sequential extraction procedure that indicated the immobilization of contaminants due to sorption, occlusion, and co-precipitation. These data help to infer the mobility and bioavailability of contaminants in the sediments, which can in turn be useful for the decision-making related to remediation of the area.

\section{Methodology}

\subsection{Study area and sampling}

The study area surrounds a former $U$ mine at Poços de Caldas Plateau (Minas Gerais State, Brazil) whose activity was ceased in 1996 leaving behind $44 \mathrm{t}$ of waste rocks that generate AMD. The waste rocks consisted of gibbsite, muscovite, kaolinite, and microcline as well as pyrite and sphalerite. The acid mine water contains mainly sulfate (2400 $\mathrm{mg} \mathrm{L}^{-1}$ ), F (100 mg L ${ }^{-1}$ ), U (8 to $12 \mathrm{mg} \mathrm{L}^{-1}$ ), Mn (up to $\left.170 \mathrm{mg} \mathrm{L}^{-1}\right)$, and $\mathrm{Zn}\left(41 \mathrm{mg} \mathrm{L}^{-1}\right)$ and has a $\mathrm{pH}$ of $\sim 3.7$ (Ladeira and Gonçalves 2007; Rodgher et al. 2013), and it is neutralized with limestone $\left(\mathrm{CaCO}_{3}\right)$ and lime $(\mathrm{CaO})$ at the water treatment unit. The treated water is released into the Águas Claras reservoir whose waters join the Antas creek. Sediment samples were taken in August 2011 from the reservoir and the Antas creek (Fig. 1). In the Águas Claras reservoir, the sediments were collected using a van Veen grab while in the Antas creek a cylindrical collector was used. Samples were placed in plastic containers and stored at $-4{ }^{\circ} \mathrm{C}$ before analysis. The sampling locations were defined by the Brazilian Environmental Agency and were labelled S1, S2, S3, S4, S5, and S6. The procedure was repeated in August 2012, and the samples were lyophilized and submitted for isotopic analysis. These samples were taken from the same sampling stations but named S1B, S2B, S3B, S4B, S5B, and S6B.

\subsection{Determination of organic carbon, total sulfur, acid volatile sulfide, simultaneously extracted metals, and toxicity of the sediments}

The total sulfur and the organic carbon $\left(f_{\text {oc }}\right)$ were determined using a LECO CS230 (Leco Corporation, St. Joseph, USA). Samples were dried at $40{ }^{\circ} \mathrm{C}$ and $2 \mathrm{~mL}$ of $\mathrm{HCl}(4 \mathrm{M})$ was added to eliminate the inorganic carbon. The samples were dried again and the residual organic carbon determined. The acid volatile sulfide (AVS) and simultaneously extracted metals (SEM) determination was in accordance with the EPA 821-R-91-100 (USEPA 1991) procedures. Wet sediments were weighed and placed in flasks with $100 \mathrm{~mL}$ of Milli-Q water, which was deaerated by bubbling $\mathrm{N}_{2}$. After $20 \mathrm{~min}, 20 \mathrm{~mL}$ of $\mathrm{HCl}(6 \mathrm{M})$ was added and the reactor was under continuous flow of nitrogen for the following $2 \mathrm{~h}$, while the volatilized sulfides were trapped in flasks with $0.5 \mathrm{M} \mathrm{NaOH}$. The acid slurry was filtered in a $0.45-\mu \mathrm{m}$ polyacetate membrane, and the metals in the filtrate $(\mathrm{Fe}$, $\mathrm{Mn}, \mathrm{Cu}, \mathrm{Cd}, \mathrm{Pb}, \mathrm{Ni}, \mathrm{Zn}$ ) were determined by flame atomic absorption spectrometry (Varian AA 240FS, Mulgrave, Australia). Detection limits were $0.03 \mathrm{mg} \mathrm{L}^{-1}$ for $\mathrm{Mn}$ and $0.1 \mathrm{mg} \mathrm{L}^{-1}$ for all the other elements. Sulfide was determined by the colorimetric method with methylene blue using a UV-VIS spectrophotometer (Varian Cary 50, Mulgrave, Australia). The calibration curve for the determination of sulfides was obtained with solutions of $\mathrm{Na}_{2} \mathrm{~S} .9 \mathrm{H}_{2} \mathrm{O}$ in concentrations between 0.2 and $1.2 \mathrm{mg} \mathrm{L}^{-1}$. The percentage of recovery was estimated based on a standard solution of $\mathrm{Na}_{2} \mathrm{~S}$, yielding results ranging between 84 and $92 \%$. 


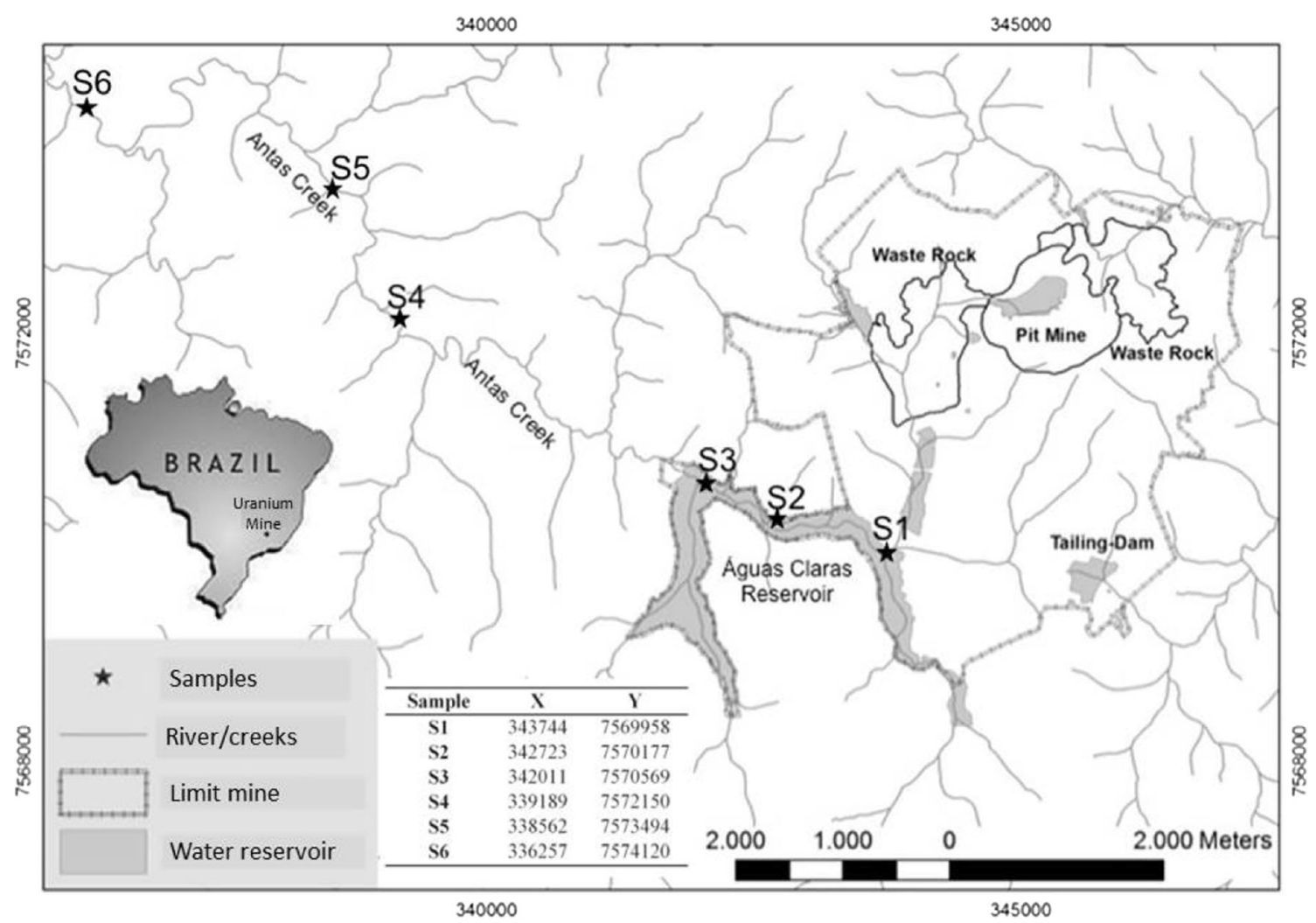

Fig. 1 Overview of the study area showing Águas Claras reservoir, the Antas creek, sampling stations (S1, S2, S3, S4, S5, and S6), and the UTM coordinates (southern hemisphere, zone 23)

The toxicity of the sediments was estimated by the difference of $\Sigma \mathrm{SEM}-\mathrm{AVS}$. If the $\Sigma \mathrm{SEM}-\mathrm{AVS} \leq 0$, the absence of toxicity can be assured; however, predicting which sediments with SEM-AVS $>0$ will be toxic is less accurate. In this case, the organic carbon was considered as additional binding phase as many dissolved metals readily bind to dissolved organic carbon forming complexes that do not appear to be bioavailable (Di Toro et al. 2005; USEPA 2005); this is a standard procedure to derive concentrations of metal mixtures in sediment, which are protective of the presence of benthic organisms (USEPA 2005). This approach was chosen because it accounts for the varying biological availability of chemicals in different sediments and allows for the incorporation of the appropriate biological effects concentration. The toxicity criteria for the sediments based on AVS, SEM, and organic carbon $\left(f_{\mathrm{oc}}\right)$ are shown in Table 1.

\subsection{Isotopic analysis}

For the isotopic analysis, three distinct sedimentary sulfur compounds were extracted from the sediments and analyzed separately: (i) the sulfur present in the AVS, (ii) the elemental and pyritic sulfur (chromium reducible sulfur (CRS)), and the (iii) water-soluble sulfate. In order to obtain the AVS and CRS fractions, the freeze-dried sediment samples were reacted with $\mathrm{HCl}(6 \mathrm{M})$ under nitrogen gas flow, liberating AVS as $\mathrm{H}_{2} \mathrm{~S}$
(Fossing and Jorgensen 1989). Subsequently, the remaining slurry was boiled for $2 \mathrm{~h}$ after the addition of acidified $\mathrm{CrCl}_{2}$ solution, and CRS was carried out in the flow as $\mathrm{H}_{2} \mathrm{~S}$. In each step, the produced sulfide was trapped in a zinc acetate solution and the $\mathrm{ZnS}$ precipitate was converted to $\mathrm{Ag}_{2} \mathrm{~S}$ by addition of $0.1 \mathrm{M} \mathrm{AgNO}_{3}$ solution. The water-soluble sulfate fraction was obtained by shaking the freeze-dried sediment with distilled water for $4 \mathrm{~h}$, followed by filtration. The filtrate containing the soluble sulfate was acidified with $\mathrm{HCl} 6 \mathrm{M}$ to a $\mathrm{pH}$ between 2 and 3 and heated for the elimination of $\mathrm{CO}_{2}$, and then the $\mathrm{BaCl}_{2}$ solution was added leading to the precipitation of sulfate as $\mathrm{BaSO}_{4}$. The stable isotope ratios of sulfur $\left({ }^{34} \mathrm{~S} /{ }^{32} \mathrm{~S}\right)$ were determined at UFZ-Centre for Environmental Research, Leipzig-Halle, Germany, using continuous-flow isotope ratio mass spectrometry (DeltaS, ThermoFinnigan, Bremen, Germany) with a reproducibility of $\pm 0.4 \%$. The sulfur isotope measurements were reported in a delta notation $\left(\delta^{34} \mathrm{~S}\right)$ as part per thousand (\%o) deviation relative to the Vienna Canon Diablo Troilite (VCDT) standard. NBS 127 was used as a primary reference material for normalization of the raw data against a standard reference.

\subsection{Sequential extraction}

The sequential extraction procedure was based on the modified Bureau Communautaire de Références (BCR) (Rauret et 
Table 1 Toxicity criteria for sediments based on AVS, SEM, and $f_{\text {oc. }}$ (adapted from USEPA 2005)

\begin{tabular}{ll}
\hline Limit values $\left(\mu \mathrm{mol} / \mathrm{g}_{\mathrm{OC}}\right)$ & Predicted biological effect \\
\hline$\Sigma \mathrm{SEM}-\mathrm{AVS} \leq 0$ & Sediment is non-toxic \\
{$\left[\frac{\Sigma \mathrm{SEM}-\mathrm{AVS}}{f_{\mathrm{oc}}}\right]<130$} & Sediment toxicity is not likely to be caused by $\mathrm{Cd}, \mathrm{Cu}, \mathrm{Pb}, \mathrm{Ni}, \mathrm{Ag}$, and $\mathrm{Zn}$ \\
$130<\frac{\Sigma \mathrm{SEM}-\mathrm{AVS}}{f_{\mathrm{oc}}}<3000$ & Sediment toxicity is uncertain due to $\mathrm{Cd}, \mathrm{Cu}, \mathrm{Pb}, \mathrm{Ni}, \mathrm{Ag}$, and $\mathrm{Zn}$ \\
$\frac{\Sigma \mathrm{SEM}-\mathrm{AVS}}{f_{\mathrm{oc}}}>3000$ & Sediment toxicity is likely to be caused by $\mathrm{Cd}, \mathrm{Cu}, \mathrm{Pb}, \mathrm{Ni}, \mathrm{Ag}$, and $\mathrm{Zn}$ \\
\hline
\end{tabular}

al. 1999). The sequential fractions were named labile (E1), reducible (E2), oxidizable (E3), and residual (E4). Among all the constituents of the sediments, the elements Fe, Mn, $\mathrm{U}$, and $\mathrm{Zn}$ were selected for investigation. Uranium analyses were carried out using a X-ray spectrometry (Kevex, model Sigma X9050, CA, USA) coupled with a radioactive source of americium $\left({ }^{241} \mathrm{Am}\right)$ and a $\mathrm{Si}(\mathrm{Li})$ detector with a detection limit of $10 \mathrm{mg} \mathrm{L}^{-1}$. Samples below this detection limit were determined by neutron activation in the Triga Mark I IPR-R1 (General Atomics, San Diego, USA) reactor, and the detection limit was $0.1 \mathrm{mg} \mathrm{L}^{-1}$. The other elements were analyzed by flame AA spectrometry (Varian AA 240FS, Mulgrave, Australia). The sum of the four fractions of $\mathrm{U}, \mathrm{Fe}, \mathrm{Mn}$ and $\mathrm{Zn}$ accounted for $82-116 \%$ of the total concentration. Detection limits were $0.13,0.03$ and $0.08 \mathrm{mg} \mathrm{L}^{-1}$ for Fe, Mn and $\mathrm{Zn}$, respectively. All reagents used for analysis were ACS grade (Merck), and reagent blanks were determined for each step of analysis.

\section{Results and discussion}

\subsection{Sulfur isotopic composition of the sediments}

The isotopic ratio $\left(\delta^{34} \mathrm{~S}\right)$ is a useful tool to provide information about the occurrence and the extension of sulfur redox processes. In sediments, there are three main inorganic fractions associated with the redox processes: (i) the AVS produced by the precipitation of biogenic hydrogen sulfide with bivalent metal ions, forming the biogenic sulfide; (ii) the CRS is comprised mostly of pyritic sulfur originated either from the aging of the biogenic sulfide and/or from geogenic pyrite, and (iii) the $\mathrm{SO}_{4}$ generated during the weathering of sulfide bearing rocks and mainly present in AMD. The $\delta^{34} \mathrm{~S}$ signatures of the three main sulfur compounds ( $\mathrm{SO}_{4}, \mathrm{AVS}$ and CRS) for each sample are presented in Fig. 2. As shown in Fig. 2, the slight variation of the $\delta^{34} \mathrm{~S}$ signatures for the $\mathrm{SO}_{4}$ throughout the reservoir and the creek indicates that this anion derives from the same sulfur source in all sediments. The average $\delta^{34} \mathrm{~S}$ value for the $\mathrm{SO}_{4}$ for all samples is $-3.03 \%$ and is within the values reported for the pyrite from the Poços de Caldas
Plateau that ranges from +1.24 to $-3.63 \%$ (Waber et al. 1992). Considering that the $\mathrm{SO}_{4}$ formed via oxidation of pyrite presents small or negligible sulfur isotope fractionation (Taylor et al. 1984; Balci et al. 2007), it may be concluded that the pyrite oxidation is the main source of sulfate. In the sediments $\mathrm{S} 4 \mathrm{~B}$ and $\mathrm{S} 6 \mathrm{~B}$, no sulfate was detected, probably because the concentrations of dissolved sulfate and $\mathrm{Ca}^{2+}$ in the creek are below the saturation limit.

According to Fig. 2, the AVS isotopic signatures were $37 \%$ for the sediments S1B and S3B; the first and last sampling station inside the reservoir. These results are consistent with those reported in the literature where the dissimilatory reduction of sulfate produces sulfide depleted in ${ }^{34} \mathrm{~S}$ up to $46 \%$ compared to the initial isotopic composition of $\mathrm{SO}_{4}$ (Rees 1973; Habicht and Canfield 1997). The sulfatereducing process and the precipitation of divalent metals with the resulting sulfide is shown in Eqs. (1) and (2), respectively:

$$
\begin{aligned}
& \mathrm{CH}_{3} \mathrm{COO}^{-}+\mathrm{SO}_{4}{ }^{2-} \rightarrow 2 \mathrm{HCO}_{3}{ }^{-}+\mathrm{HS}^{-} \\
& \mathrm{HS}^{-}+\mathrm{M}^{2+} \rightarrow \mathrm{MS}+\mathrm{H}^{+}
\end{aligned}
$$

where the acetate $\mathrm{CH}_{3} \mathrm{COO}^{-}$represents dissolved organic carbon, although other organic compounds may be found. A

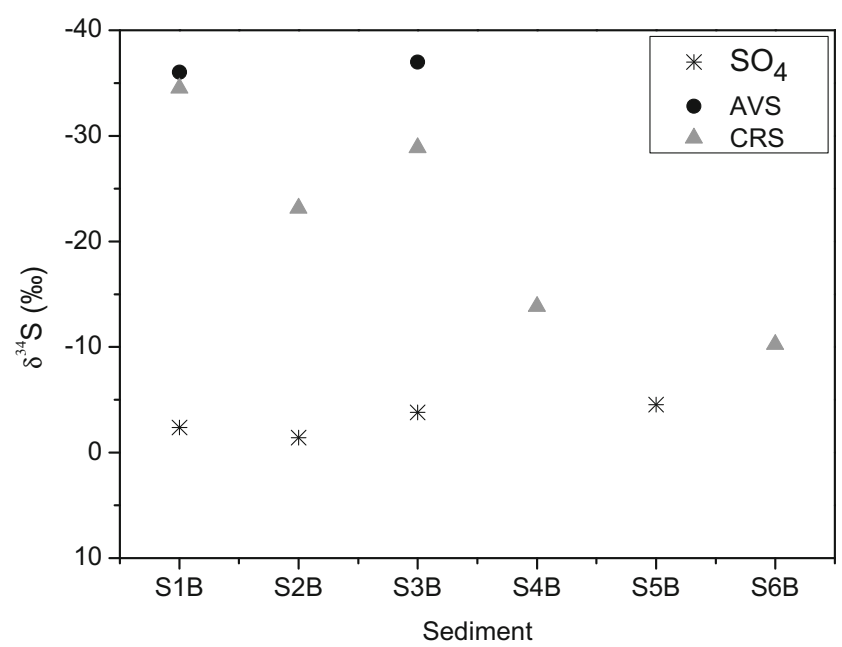

Fig. 2 Isotopic signatures of the fractions $\mathrm{SO}_{4}, \mathrm{AVS}$, and CRS for the surface sediments 
group of anaerobic microorganisms, mainly bacteria and archaea (Muyzer and Stams 2008), reduce sulfate $\left(\mathrm{SO}_{4}{ }^{2-}\right)$ to sulfide $\left(\mathrm{S}^{2-}\right)$ using organic electron donors through dissimilatory reduction. The sulfate reduction consumes protons, consequently increasing the $\mathrm{pH}$ and yielding sulfides which react with metals (e.g., $\mathrm{Fe}, \mathrm{Zn}, \mathrm{Cu}, \mathrm{Cd}, \mathrm{Ni}$, and $\mathrm{Pb}$ ), leading to the precipitation of insoluble metal sulfides. Most of the sulfatereducing bacteria are neutrophilic, thriving at a $\mathrm{pH}$ between 6 and 8. However, the existence of acidophilic bacteria is also reported, offering the possibility to form insoluble metal sulfides without the need of prior neutralization of the AMD (Sánchez-Andrea et al. 2014).

Commonly, iron is the most abundant divalent metal in the pore water of sediments and susceptible to sulfide precipitation; therefore, iron sulfides can be the predominant phase in AVS (Rickard and Morse 2005). Once the FeS is formed, three main mechanisms have been reported for the formation of neogenic pyrite: (i) a reaction in anoxic conditions (Eq. 3), (ii) a reaction with reduced sulfur or polysulfur (Eq. 4) and (iii) a direct precipitation of dissolved sulfides with iron oxides (Eq. 5) (Lesven et al. 2008):

$$
\begin{aligned}
& \mathrm{FeS}+\mathrm{H}_{2} \mathrm{~S} \rightarrow \mathrm{FeS}_{2}+\mathrm{H}^{+} \\
& \mathrm{FeS}+1 / 8 \mathrm{~S}_{8} \rightarrow \mathrm{FeS}_{2}
\end{aligned}
$$

$\mathrm{FeOOH}+3 / 2 \mathrm{HS}^{-}+1 / 16 \mathrm{~S}_{8}+3 / 2 \mathrm{H}^{+} \rightarrow \mathrm{FeS}_{2}+2 \mathrm{H}_{2} \mathrm{O}$

The $\delta^{34} \mathrm{~S}$ values for CRS inside the reservoir, from -21 to $-33 \%$, are between the AVS and the $\mathrm{SO}_{4}$ values, which indicate the presence of primary sedimentary pyrite as well as neogenic pyrite formed by the bacterial reduction process. In contrast, the $\delta^{34} \mathrm{~S}$ value for CRS in the Antas creek were more enriched and closer to the sulfate isotopic value and thus to the $\delta^{34} \mathrm{~S}$ value of $-3.03 \%$ for pyrite in the region. Therefore, inside the Águas Claras reservoir, the bacterial sulfate reduction is a significant process resulting in the precipitation of metallic sulfides and the formation of neogenic pyrite, capable of occluding contaminants in its structure.

\subsection{Acid volatile sulfide and simultaneously extracted metals}

Once the bacterial reduction of the sulfate was confirmed by isotopic studies, the next step was the assessment of the extension of the reduction process through the quantification of sulfides and their bonded metals (i.e., AVS-SEM) (USEPA 1991). The AVS fraction comprises the free sulfides $\left(\mathrm{S}^{2-}\right)$, iron sulfides such as $\mathrm{FeS}$ (mackinawite) and $\mathrm{Fe}_{3} \mathrm{~S}_{4}$ (greigite) (Rickard and Morse 2005), and sulfides from bivalent metals such as $\mathrm{Cu}, \mathrm{Ni}, \mathrm{Zn}, \mathrm{Cd}$, and $\mathrm{Pb}$. The SEM fraction is composed of the metals, normally $\mathrm{Cd}, \mathrm{Cu}, \mathrm{Pb}, \mathrm{Ni}, \mathrm{Hg}, \mathrm{Ag}$, and $\mathrm{Zn}$, liberated from the sediment during the acidification. In the present work, the concentrations of $\mathrm{Ni}, \mathrm{Cu}$, and $\mathrm{Cd}$ were below the detection limit $\left(0.1 \mathrm{mg} \mathrm{L}^{-1}\right)$ and considered not relevant. The results for AVS, metals extracted in the SEM, organic carbon $\left(f_{\mathrm{oc}}\right)$, and total sulfur $\left(S_{\mathrm{Tot}}\right)$ are shown in Table 2.

As shown in Table 2, there is a significant variability in the content of AVS in the sediments, ranging from 3 to $2969 \mathrm{mg} \mathrm{kg}^{-1}$, which indicates different environmental conditions that may be unsuitable for the formation and precipitation of AVS phases. For instance, sediments S1 and S4 presented the lowest AVS concentrations, 150 and $3 \mathrm{mg} \mathrm{kg}^{-1}$, respectively, as well as the lowest concentration of organic carbon, 5.584 and $10.214 \mathrm{mg} \mathrm{kg}^{-1}$, respectively, and Eh of 66.4 and $58.8 \mathrm{mV}$, respectively. For sediment $\mathrm{S} 1$, the high content of total sulfur is associated with insoluble phases of sulfate, carried from the water treatment station, which contains ettringite $\left(\mathrm{Ca}_{6} \mathrm{Al}_{2}\left(\mathrm{SO}_{4}\right)_{3}(\mathrm{OH})_{12} \cdot 26 \mathrm{H}_{2} \mathrm{O}\right)$ and gypsum $\left(\mathrm{CaSO}_{4} .2 \mathrm{H}_{2} \mathrm{O}\right)$ (Gomes et al. 2012). The other samples inside the reservoir (S2 and S3) present high AVS, $3000 \mathrm{mg} \mathrm{kg}^{-1}$, and the greatest amount of organic carbon. These results corroborate the bacterial reduction activity suggested by isotopic fractionation and indicate that the sulfide production is prolific, leading to precipitation of metallic ions and reducing the availability of metals. Furthermore, the bacterial reduction could be one of the reasons behind the decreasing sulfate content in the waters downstream of the reservoir, as reported in the Technical Report of the Water Committee (Comissão das Águas 2012). According to this report, the concentration of sulfate in the water at the station $\mathrm{S} 1$ was $290 \mathrm{mg} \mathrm{L}^{-1}$ while at station $\mathrm{S} 2$ the value was $135 \mathrm{mg} \mathrm{L}^{-1}$.
Table 2 Organic carbon $\left(f_{\text {oc }}\right)$, total sulfur $\left(S_{\text {Tot }}\right)$, AVS, and metals extracted in the SEM procedure

\begin{tabular}{llllllll}
\hline & $\begin{array}{l}f_{\mathrm{oc}} \\
\left(\mathrm{g} \mathrm{kg}^{-1}\right)\end{array}$ & $\begin{array}{l}S_{\mathrm{Tot}} \\
\left(\mathrm{g} \mathrm{kg}^{-1}\right)\end{array}$ & $\begin{array}{l}\mathrm{AVS} \\
\left(\mathrm{mg} \mathrm{kg}^{-1}\right)\end{array}$ & $\begin{array}{l}\mathrm{Fe} \\
\left(\mathrm{g} \mathrm{kg}^{-1}\right)\end{array}$ & $\begin{array}{l}\mathrm{Mn} \\
\left(\mathrm{mg} \mathrm{kg}^{-1}\right)\end{array}$ & $\begin{array}{l}\mathrm{Zn} \\
\left(\mathrm{mg} \mathrm{kg}^{-1}\right)\end{array}$ & $\begin{array}{l}\mathrm{Pb} \\
\left(\mathrm{mg} \mathrm{kg}^{-1}\right)\end{array}$ \\
\hline S1 & 5.6 & 11.6 & 151 & 34.5 & 7184 & 5845 & 24 \\
S2 & 22.2 & 13.0 & 2665 & 42.5 & 184 & 1375 & 35 \\
S3 & 23.6 & 9.9 & 2969 & 31.7 & 300 & 1561 & 37 \\
S4 & 10.2 & 2.0 & 3 & 11.9 & 917 & 160 & 23 \\
S5 & 25.5 & 4.2 & 133 & 21.1 & 2058 & 188 & 23 \\
S6 & 21.4 & 3.2 & 58 & 17.9 & 789 & 101 & 30 \\
\hline
\end{tabular}


Despite the high concentrations of organic carbon in the sediments S5 and S6, compared to S2 and S3, the content of AVS is much lower, i.e., of 133 and $58 \mathrm{mg} \mathrm{kg}^{-1}$, respectively, which implies that bacterial reduction processes are not pronounced. This fact may be associated with the low content of sulfate in the waters of Antas creek $\left(\sim 35 \mathrm{mg} \mathrm{L}^{-1}\right)$, much lower than the values in the reservoir. In addition, the higher water flow in Antas creek results in an oxic environment, hindering the bacterial sulfate reduction and the formation of metals sulfides. Table 2 also shows the metals, Fe, Mn, Zn, and Pb, extracted in the AVS-SEM procedure after the dissolution of the biogenic metallic sulfides as well as the amorphous and crystalline phases of $\mathrm{Fe}$ and $\mathrm{Mn}$. According to Table 1, the toxicity of the sediments that can affect the benthic organisms can be estimated by the difference ( $\mathrm{SEEM}-\mathrm{AVS}$ ) which is based upon the chemical interactions of metal-sulfide and the equilibrium partitioning theory (Di Toro et al. 2005). When there is an excess of sulfide, the metals precipitate as insoluble phases, such as $\mathrm{NiS}, \mathrm{ZnS}, \mathrm{CdS}, \mathrm{PbS}, \mathrm{CuS}$, and $\mathrm{Ag}_{2} \mathrm{~S}$, whose preference for precipitation depends on their solubility product $\left(K_{\mathrm{ps}}\right)$. As a result, the metals are sequestrated from the aqueous phase, what decreases their activity and, consequently, their bioavailability. The results for the assessment of toxicity based upon the difference ( $\Sigma$ SEM - AVS $)$ and the normalized difference $\left((\Sigma \mathrm{SEM}-\mathrm{AVS}) / f_{\text {oc }}\right)$ for all the sediments are shown in Table 3. According to Table 3, the sediments S2 and S3 (inside the Águas Claras reservoir) and the sediments $\mathrm{S} 5$ and $\mathrm{S} 6$ (in the river) were classified as non-toxic, since the difference of $\Sigma$ SEM - AVS were negative. On the other hand, the sediments $\mathrm{S} 1$ and S4 presented positive value, i.e., $(\Sigma$ SEM - AVS $)>0$, and were normalized by the fraction of organic carbon $\left(f_{\text {oc }}\right)$. According to these criteria, the sample S4 presented uncertain toxicity once the value of $\Sigma$ SEM - AVS $) / f_{\text {oc }}$ is between 130 and $3000 \mu \mathrm{mol} \mathrm{goc}^{-1}$. The sediment S1 presented $(\Sigma \mathrm{SEM}-\mathrm{AVS}) / f_{\mathrm{oc}}>3000 \mu \mathrm{mol} \mathrm{g}_{\mathrm{OC}}{ }^{-1}$, which implies high risk of adverse biological effects mainly due to the high content of $\mathrm{Zn}$. As will be discussed in the sequential extraction results below, the sample S1 was strongly affected by the overflow of sludge from the water treatment unit.
In conclusion, the results show that the soluble sulfate from the reservoir undergoes bacterial reduction producing sulfide. The $\mathrm{S}^{2-}$ can precipitate divalent metals, particularly $\mathrm{Zn}$, producing highly insoluble metal sulfides which decrease the availability to the environment. Therefore, despite the high levels of total metals in most sediment, samples S2, S3, S5, and $\mathrm{S} 6$ were assessed as non-toxic. On the other hand, the sediments S1 and S4 present low amounts of sulfide; consequently, sample S1 is likely to be toxic, whereas for S4, the biological adverse effects are uncertain. Therefore, it is recommended to monitor the redox potential once its increase can promote the oxidization of sulfides as well as the degradation of organic compounds, accelerating the liberation of the adsorbed/complexed metals (Zhang et al. 2014). Furthermore, an increase in the redox potential can also inhibit the activity of anaerobic sulfate-reducing bacteria and thus hamper the production of sulfides.

\subsection{Sequential extraction}

The AVS procedure takes into account only the elements $\mathrm{Cu}$, $\mathrm{Zn}, \mathrm{Pb}, \mathrm{Ni}, \mathrm{Cd}$, and $\mathrm{Ag}$ in the estimation of the toxicity of the samples. Consequently, other toxic metals present in sediments are not assessed by this method. However, as the study area presents other elements, such as $\mathrm{U}$ and $\mathrm{Mn}$, additional methods should be used to identify their association with different mineralogical phases and, consequently, their availability to the environment. Thus, sequential extraction experiments were carried out and four elements were selected to be evaluated: $\mathrm{Fe}$ and $\mathrm{Mn}$, because they are considered as a sink for contaminants (Filgueiras et al. 2002), and Zn and U because they are present in high levels in sediments, besides their toxicity. Figure 3 shows the sequential extraction results as well as the total metal concentration in the original samples. It is noted that the sample station S1 presents the highest concentration of $\mathrm{Mn}, \mathrm{Zn}$, and $\mathrm{U}$ (7417, 5285, and $3600 \mathrm{mg} \mathrm{kg}^{-1}$, respectively) followed by samples $\mathrm{S} 2$ and $\mathrm{S} 3$ that are also enriched in $\mathrm{U}$ and $\mathrm{Zn}$ if compared to the sediments in the Antas creek. This enrichment is caused by part of
Table 3 Results of sediment toxicity based upon the difference ( $\Sigma$ SEM - AVS) and the normalized difference $\left.(\Sigma \mathrm{SEM}-\mathrm{AVS}) / f_{\text {oc }}\right)$

\begin{tabular}{|c|c|c|c|c|c|}
\hline Sample & $\begin{array}{l}\text { AVS } \\
\left(\mu \mathrm{mol} \mathrm{g}{ }^{-1}\right)\end{array}$ & $\begin{array}{l}\sum \mathrm{SEM} \\
\left(\mu \mathrm{mol} \mathrm{g}{ }^{-1}\right)\end{array}$ & $\begin{array}{l}f_{\text {oc }} \\
\left(\mathrm{g}_{\mathrm{OC}} \mathrm{g}^{-1}\right)\end{array}$ & $\begin{array}{l}(\Sigma \mathrm{SEM}-\mathrm{AVS}) \\
\left(\mu \mathrm{mol} \mathrm{g}{ }^{-1}\right)\end{array}$ & $\begin{array}{l}(\Sigma \mathrm{SEM}-\mathrm{AVS}) / f_{\mathrm{oc}} \\
\left(\mu \mathrm{mol} \mathrm{goC}^{-1}\right)\end{array}$ \\
\hline S1 & 4.70 & 89.40 & 0.006 & 84.70 & 15,168 \\
\hline S2 & 83.11 & 21.20 & 0.022 & -61.91 & -2785 \\
\hline S3 & 92.58 & 24.05 & 0.024 & -68.53 & -2913 \\
\hline S4 & 0.10 & 2.56 & 0.010 & 2.46 & 241 \\
\hline S5 & 4.15 & 2.98 & 0.025 & -1.17 & -46 \\
\hline S6 & 1.82 & 1.70 & 0.021 & -0.13 & -6 \\
\hline
\end{tabular}

$g_{O C}$ gram of organic carbon 

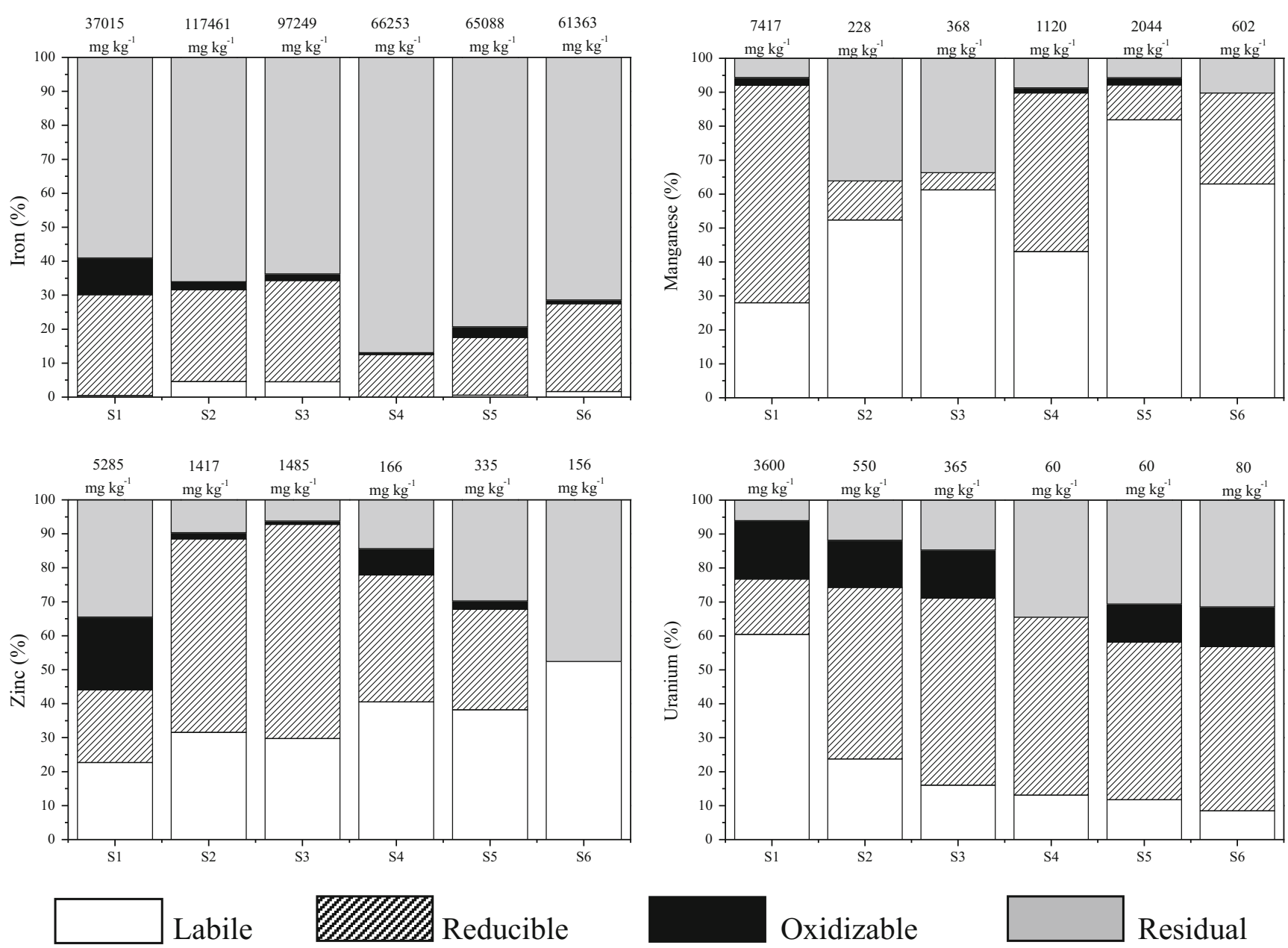

Fig. $3 \mathrm{Mn}, \mathrm{Zn}, \mathrm{U}$, and Fe partitioning in the sediments, according to $\mathrm{mBCR}$ procedure. The total concentration is displayed on the top of each column

the precipitate that overflows from the water treatment unit and settles at the bottom of the reservoir.

Iron As shown in Fig. 3, minor amounts of Fe were associated with the labile and oxidizable fractions. However, it was mainly extracted in the reducible and residual steps which are similar to the results reported in the literature (Morillo et al. 2008; Charriau et al. 2011). The reducible fraction (E2) comprises 12 to $30 \%$ and consists of oxyhydroxides present in highly weathered environments (amorphous Fe). In the sediments, these amorphous phases are important sinks for contaminants, since they have a high capacity of adsorbing other metals in their structure (Filgueiras et al. 2002). The small portion of Fe extracted in the oxidizable fraction is associated with organic matter and sulfides. In all sediments, Fe was preferentially associated with the residual fraction comprising crystalline forms of hematite and goethite, in addition to aluminossilicates containing Fe (II and III) and pyrite.

Manganese High percentage of Mn (28 to $81 \%$ ) was extracted in the labile fraction (E1), most likely due to its association with the carbonate phases formed in the water treatment unit as reported by Gomes et al. (2012). In the reducible fraction E2 (i.e., amorphous Fe oxides and crystalline Mn oxides; Filgueiras et al. 2002), it was extracted 5 to $64 \%$ of the Mn. The highest extraction was for sample $\mathrm{S} 1$ which also presented the highest Mn content. The oxidizable fraction (E3) seems to be irrelevant as it represents at maximum of $2 \%$ of the Mn. This is explained by the low content of Mn sulfides as well as the difficulty of $\mathrm{Mn}$ to form complexes with organic matter. The Mn present in the residual fraction, which comprises the phases resistant to the weathering and bonded to lithogenic minerals, ranged from 6 to $36 \%$.

Zinc The mobility of $\mathrm{Zn}$ is evidenced by the high levels of extraction in the labile fraction E1 (20 to $50 \%$ ) indicating that it could be mainly weakly adsorbed, easily exchangeable, and/ or co-precipitated with carbonates (Filgueiras et al. 2002). The labile fraction is also associated with the extraction of $\mathrm{Zn}$ precipitated as AVS, since the sample drying may result in the oxidation of the sulfides, increasing the amount of $\mathrm{Zn}$ extracted. Since metals in the labile fraction are considered readily and potentially bioavailable, the $\mathrm{Zn}$ associated to this fraction is of concern for the samples S1, S2, and S3, which 
contain high levels of zinc (5285 to $2417 \mathrm{mg} \mathrm{kg}^{-1}$ ). These results corroborate the findings in the AVS-SEM approach, in which sample S1 was classified as likely to be toxic due to the great amount of $\mathrm{Zn}$ which is highly bioavailable. Inside the reservoir, samples S2 and S3 have around $60 \%$ of total $\mathrm{Zn}$ extracted in the reducible fraction, mainly in the form of $\mathrm{Zn}$ oxide and/or adsorbed in $\mathrm{Fe}$ oxyhydroxides since almost $30 \%$ of total $\mathrm{Fe}$ is extracted in this phase. The association of $\mathrm{Zn}$ in $\mathrm{Fe}-\mathrm{Mn}$ oxides/hydroxides confirms the known ability of this phase to scavenge $\mathrm{Zn}$ from the aqueous phase, and these phases are completely extracted during the AVS-SEM procedure. The sediment S1 was the only one to present significant amount of $\mathrm{Zn}$ associated with the oxidizable fraction. Since this sediment presented low contents of organic matter and sulfides, $\mathrm{Zn}$ was probably associated with other oxidizable phases such as CRS-Fe. Despite the elevated content of organic matter in the other samples, only $2 \%$ of total $\mathrm{Zn}$ was extracted in the oxidizable fraction, indicating it is not significant as a binding phase. The $\mathrm{Zn}$ extracted in the residual fraction indicates the presence of sphalerite $\mathrm{ZnS}$, a mineral found in the region, and in part contributes to the acid mine generation. The $\mathrm{Zn}$ inside the Águas Claras reservoir is mainly present in sediments due to reactions of precipitation, complexation, and/or adsorption, which enrich the levels of this element in the labile and reducible fractions.

Uranium The sample $\mathrm{S} 1$ presented the highest extraction of $\mathrm{U}$ in the labile fraction, $\sim 60 \%$, most likely due to the presence of calcium diuranate $\left(\mathrm{CaU}_{2} \mathrm{O}_{7}\right)$ that overflowed from the water treatment unit (Gomes et al. 2012). Minor amounts of U were extracted in the labile fraction in the other sediments, ranging from 2 to $23 \%$. For these samples, $\mathrm{U}$ can be non-specifically adsorbed on the surface of clays or on Fe and $\mathrm{Mn}$ oxyhydroxides. The presence of the $\mathrm{U}$ in the labile fraction is particularly worrying as its high concentration$3600 \mathrm{mg} \mathrm{kg}^{-1}$ in sample S1, for instance - can pose risks to the environment. However, it is interesting to note that the $\mathrm{U}$ content in the labile fraction decreases with distance from upstream to downstream the lake, i.e., from sample S1 to S6. In all samples except $\mathrm{S} 1$, most of the $\mathrm{U}$ is associated with the $\mathrm{Mn}$ and Fe oxyhydroxides (step E2), most likely due to the sorption or occlusion of $\mathrm{U}$ in hematite $\left(\mathrm{Fe}_{2} \mathrm{O}_{3}\right)$ and goethite $\left(\mathrm{Fe}_{3} \mathrm{O}_{4}\right)$ (Duff et al. 2002). The lower extraction of $\mathrm{U}$ in step E2 for sample S1, $\sim 15 \%$, is related to the low content of Fe in this sample. The $U$ in the oxidizable fraction E3 is $\sim 15 \%$ and represents the U sorbed in the organic matter (Duff et al. 2002) and/or the U reduced into crystalline oxides (e.g., uraninite) in an effective mechanism of bioremediation. Sample S4, the only one without $\mathrm{U}$ in the oxidizable fraction, is also the one which presented the lowest level of total sulfur and organic matter. Significant contents of $U$ in the residual fraction are found in sediments S4, S5, and S6, 30\%. The U in these sediments may be included in the crystalline iron oxides, silicates, and gibbsite or as uraninite; all of them are typical minerals of the region. On the other hand, the S1, S2, and S3 samples, collected inside the reservoir, showed a low content of $U$ associated with the residual fraction (6 to $14 \%$ ), which reinforces the contamination of the lake by $U$ solid phases with great bioavailability.

\section{Conclusions}

The results indicate that the Antas creek seems not to be affected by the AMD, while the environmental impact appears to be concentrated in the Águas Claras reservoir and this has been caused by an enrichment of metals in its sediments. Among the samples, point S1 was particularly affected by the discharge of treated effluent as shown by the elevated concentrations of $\mathrm{Zn}(0.5 \%)$, Mn (0.7 \%), and U (0.4 \%). In addition, according to the AVS-SEM analyses, the sample S1 is likely to be toxic, probably due to the high content of $\mathrm{Zn}$. All the other samples are unlikely to be toxic or present uncertain toxicity. The isotopic sulfur investigation in the Antas creek showed no evidence of bacterial sulfate reduction, and this is confirmed by the presence of geogenic pyritic typical of the geology of the region. Sequential extraction showed U, $\mathrm{Zn}$, and Mn mostly present in the labile fraction and reducible phase. For this reason, special attention should be given to the sediments inside the reservoir to avoid the spread of the contaminants. Therefore, to prevent later mobilization of the metals it is recommended that the sediments remain in anoxic conditions, thus hindering the re-dissolution of the main scavenging phases.

It is worth mentioning that the present work is a contribution to the remediation of areas contaminated with metals, including radioactive and non-radioactive elements. The full characterization of the bioremediation process, as well as the definition of the chemical availability of the contaminants, could help determine the best remediation plan for such areas, which could be the complete removal of the sediments or the improvement of the bioremediation process. The enhancement of the bacterial sulfate reduction has the advantage of promoting the formation of metal sulfides as well as the reduction of the highly soluble U(VI) to a less soluble U(IV). In addition, the understanding of the natural processes provided by this investigation could lead to possible strategies for artificial immobilization of the metals.

Acknowledgments The authors thank CAPES, FAPEMIG, and CNPq-INCT-Acqua, PPM, CT Mineral-for the financial support and the staff of the Stable Isotope Laboratory of UFZ (Leipzig-Halle) for their isotopic analytical assistance. Also, the authors gratefully acknowledge the comments offered by the editor and two anonymous reviewers. 
Open Access This article is distributed under the terms of the Creative Commons Attribution 4.0 International License (http:// creativecommons.org/licenses/by/4.0/), which permits unrestricted use, distribution, and reproduction in any medium, provided you give appropriate credit to the original author(s) and the source, provide a link to the Creative Commons license, and indicate if changes were made.

\section{References}

Balci N, Shanks WC, Mayer B, Mandernack KW (2007) Oxygen and sulfur isotope systematics of sulfate produced by bacterial and abiotic oxidation of pyrite. Geochim Cosmochim Acta 71:3796-3811

Brunner B (2005) A revised isotope fractionation model for dissimilatory sulfate reduction in sulfate reducing bacteria. Geochim Cosmochim Acta 69:4759-4771

Byrne P, Reid I, Wood PJ (2010) Sediment geochemistry of streams draining abandoned lead/zinc mines in central Wales: the Afon Twymyn. J Soils Sediments 10:683-697

Charriau A, Lesven L, Gao Y, Leermakers M, Baeyens W, Ouddane B, Billon G (2011) Trace metal behaviour in riverine sediments: role of organic matter and sulfides. Appl Geochemist 26:80-90

Comissão das Águas (2012) Avaliação da qualidade das águas e sedimentos das microbacias do Ribeirão das Antas e do Ribeirão de Caldas no Planalto de Poços de Caldas - Relatório Técnico da Comissão das Águas. Available at: pocosdecaldas.mg.leg.br/ index.php?download = 52. Accessed 25 Sep 2015

Di Toro DM, McGrath JA, Hansen DJ, Berry WJ, Paquin PR, Mathew R, Wu KB, Santore RC (2005) Predicting sediment metal toxicity using a sediment biotic ligand model: methodology and initial application. Environ Toxicol Chem 24:2410-24127

Duff MC, Coughlin JU, Hunter DB (2002) Uranium co-precipitation with iron oxide minerals. Geochim Cosmochim Acta 66:3533-3547

Filgueiras AV, Lavilla I, Bendicho C (2002) Chemical sequential extraction for metal partitioning in environmental solid samples. J Environ Monit 4:823-857

Fossing H, Jorgensen B (1989) Measurement of bacterial sulfate reduction in sediments: evaluation of a single-step chromium reduction method. Biogeochemistry 8:205-222

Gomes AFS, Lopez DL, Ladeira ACQ (2012) Characterization and assessment of chemical modifications of metal-bearing sludges arising from unsuitable disposal. J Hazard Mater 199-200:418-425

Habicht KS, Canfield DE (1997) Sulfur isotope fractionation during bacterial sulfate reduction in organic-rich sediments. Geochim Cosmochim Acta 61:5351-5361

Knöller K, Fauville A, Mayer B, Strauch G, Friese K, Veizer J (2004) Sulfur cycling in an acid mining lake and its vicinity in Lusatia, Germany. Chem Geol 204:303-323

Ladeira ACQ, Gonçalves CR (2007) Influence of anionic species on uranium separation from acid mine water using strong base resins. J Hazard Mater 148:499-504
Lesven L, Gao Y, Billon G, Leermakers M, Ouddane B, Fischer JC, Baeyens W (2008) Early diagenetic processes aspects controlling the mobility of dissolved trace metals in three riverine sediment columns. Sci Total Environ 407:447-459

Morillo J, Usero J, Rojas R (2008) Fractionation of metals and As in sediments from a biosphere reserve (Odiel salt marshes) affected by acidic mine drainage. Environ Monit Assess 139:329-337

Muyzer G, Stams AJM (2008) The ecology and biotechnology of sulphate-reducing bacteria. Nat Rev Microbiol 6:441-454

Rauret G, López-Sánchez JF, Sahuquillo A, Rubio R, Davidson C, Ure AM, Quevauviller P (1999) Improvement of the BCR three step sequential extraction procedure prior to the certification of new sediment and soil reference materials. J Environ Monit 1:57-61

Rees CE (1973) A steady-state model for sulphur isotope fractionation in bacterial reduction processes. Geochim Cosmochim Acta 37:11411162

Rickard D, Morse JW (2005) Acid volatile sulfide (AVS). Mar Chem 97: 141-197

Rodgher S, de Azevedo H, Ferrari CR, Roque CV, Ronqui LB, de Campos MB, Nascimento MRL (2013) Evaluation of surface water quality in aquatic bodies under the influence of uranium mining (MG, Brazil). Environ Monit Assess 185:2395-2406

Sánchez-Andrea I, Sanz JL, Bijmans MFM, Stams AJM (2014) Sulfate reduction at low $\mathrm{pH}$ to remediate acid mine drainage. J Hazard Mater 269:98-109

Sarmiento AM, Olías M, Nieto JM, Cánovas CR, Delgado J (2009) Natural attenuation processes in two water reservoirs receiving acid mine drainage. Sci Total Environ 407:2051-2062

Seal RR (2003) Stable-isotope geochemistry of mine waters and related solids. In: Jambor JL, Blowes DW, Ritchie AIM (eds) Environmental aspects of mine wastes, Miner. Soc. Canada, Short Course Series 31., pp 303-334

Taylor BE, Wheeler MC, Nordstrom DK (1984) Isotope composition of sulphate in acid mine drainage as measure of bacterial oxidation. Nature 308:538-541

USEPA (1991) Draft analytical method for determination of acid volatile sulfide and selected simultaneously extractable metals in sediment. EPA-821-R-91-100. US Environmental Protection Agency, Washington, DC

USEPA (2005) Procedures for the derivation of equilibrium partitioning sediment benchmarks (ESBs) for the protection of benthic organisms: metal mixtures (cadmium, copper, lead, nickel, silver and zinc). EPA-600-R-02-011. US Environmental Protection Agency, Washington, DC

Waber N, Schorscher HD, Peters T (1992) Hydrothermal and supergene uranium mineralization at the Osamu Utsumi mine, Poços de Caldas, Minas Gerais, Brazil. J Geochem Explor 45:53-112

Zhang C, Yu Z, Zeng G, Jiang M, Yang Z, Cui F, Hu L (2014) Effects of sediment geochemical properties on heavy metal bioavailability. Environ Int 73:270-281 